\title{
Spousal Communication and Contraceptive Use among Married Couples in Rural Areas of Akwa Ibom State, Nigeria
}

\author{
Asa, U. A. \\ Department of Agricultural Economics and Extension, \\ University of Uyo, Uyo, Akwa Ibom State, Nigeria \\ Nkan, V. V. \\ Department of Human Ecology, Nutrition and Dietetics, \\ University of Uyo, Uyo, Akwa Ibom State, Nigeria \\ Okoro, G. I. \\ Department of Agricultural Economics and Extension, \\ University of Uyo, Uyo, Akwa Ibom State, Nigeria
}

Doi: 10.2478/jesr-2018-0006

\begin{abstract}
The study ascertained the influence of spousal communication about family planning on contraceptive use among married couples in the rural areas of Akwa Ibom State, Nigeria. Data for the study were obtained from one hundred and fifty married couples using multi-stage sampling procedure. The data were analyzed using descriptive statistics and multiple regression. Results indicate that $71.3 \%$ of the respondents were females with an average age of 38 years while $28.7 \%$ of them were males with an average age of 49 years; fourteen years was the respondents' average years of marriage. Findings also show that barrier methods, hormonal contraceptives and injectables were the contraceptive methods highly used by the respondents; and majority of the married couples had a favourable spousal communication about family planning disposition. Multiple regression analysis result shows that contraceptive use by the respondents was significantly influenced by their spousal communication about family planning. It is recommended, among others, that intervention programmes of Governmental and Non-Governmental agencies in Akwa Ibom State emphasize the importance of spousal communication about family planning in their programmes and encourage same among targeted beneficiaries of such programmes.
\end{abstract}

Keywords: Spousal, family planning, contraceptives, rural, Akwa Ibom

\section{Introduction}

Over the years, there has been an alarming increase in the population of many developing countries (May, 2012). Nigeria, a developing country, is the most populous country in Africa accounting for approximately one-sixth of the continent's population (Asa and Daniel, 2015). The National Population Commission/Federal Ministry of Health (NPC/FMOH) reported that Nigeria adds about 3.5 million people to its population annually (NPC/FMOH, 2004). This alarming population growth has serious implications. Okoroafor (2001) reported that the high population growth rate in Nigeria, especially in the face of low productivity, have directly or indirectly been associated with different kinds of social problems ranging from poverty, scarcity of land, hunger, 
and environmental degradation to political instability. Malnutrition, human waste, air borne diseases form the core disease pattern of developing countries with increasing populations (Asthana and Asthana, 2006). The efforts of the governments in the developing countries to feed their people and also provide quality social services for them are being frustrated by rapid population growth (Adewole, 2012). Family planning has, however, been advocated as a control mechanism to regulate and control the rapid population growth in Nigeria (Undelikwo et al., 2013).

Family planning plays a vital role in population control, poverty reduction and human development (Longwe et al., 2012). The use of contraceptives, as an important family strategy, has led to the control of fertility through prevention of unintended and unwanted pregnancies thereby reducing rapid population growth in many nations of the world (Ukpong, 2016). Families that adopt/use contraceptives have been reported to have more assets, live in more valuable houses and have better educated children than families that do not use contraceptives (Eastwood and Lipton, 2001; Adeoti et al., 2009), thereby buttressing the importance of the use of contraceptives.

Spousal communication is an important basis for decision making about reproductive health, sexual needs, desired family size, contraceptive adoption/use of modern methods of family planning and several other issues by couples (Islam et al., 2014). And, spousal communication is strongly associated with contraceptive use (Sharan and Valente, 2002; Akanbi et al., 2011). However, there is a dearth of information on the relationship between spousal communication and contraceptive use in the rural areas of Akwa Ibom State. When relatively little is known about reproductive decision-making, Kamal (1999) posited that studies on the processes and outcomes are important for both programmatic and theoretical reasons. Hence, this study which ascertained the influence of spousal communication on use of contraceptives by married couples in the rural areas of Akwa Ibom State, Nigeria. This study is particularly germane since the high population problem in the rural areas of Akwa Ibom State is more acute than the urban areas (Asa, 2006). The specific objectives of the study were to:

$>$ examine the demographic characteristics of married couples in the rural areas of Akwa Ibom State, Nigeria,

$>$ ascertain the respondents' spousal communication about family planning disposition,

$>$ assess the level of use of contraceptives by the respondents, and

$>$ determine the influence of spousal communication about family planning on use of contraceptives by the respondents.

\section{Methodology}

The study was conducted in Akwa Ibom State of Nigeria. The State lies between $4{ }^{0} 33^{\prime \prime}$ and $5^{\circ} 33^{\prime \prime}$ North latitudes and $7^{0} 35$ " and $8^{0} 25^{\prime \prime}$ East longitudes, and is wedged between Cross River, Abia and Rivers State of Nigeria. It has an estimated population of 3,920, 208 and occupies a total land area of $7,245,935 \mathrm{~km}^{2}$ (National Population Commission, 2006). Akwa Ibom State is characterized by two major seasons - the dry season and the rainy season (Asa and Solomon, 2015). A multi-stage sampling procedure was used to select the respondents for the study. The first stage of the multistage sampling procedure involved the simple random selection of three out of the six Agricultural Development Project (ADP) zones in Akwa Ibom State. The selected zones were Oron, Uyo and Abak. The second stage involved the purposive selection of fifty households from rural areas in each of the three selected ADP zones. Purposive sampling was employed to ensure that only households in the rural areas of the zones were selected for the study. Furthermore, a married couple in each of the selected households was randomly selected for the study thereby resulting in a total sample size of 150 married couples.

The demographic characteristics of the married couples were analyzed using descriptive statistics such as frequency counts, percentages and means. The respondents' spousal communication about family planning disposition was ascertained by requesting the married couples to respond to statements in a 30 -item Marital Communication Inventory $(\mathrm{MCl})$. The $\mathrm{MCl}$ used for the study was a 3-point rating scale with nominal values assigned to the points in the scale as follows: Never $=0$, Rarely $=1$ and Often $=2$ for positive statements; and Never $=2$, Rarely $=1$ and Often $=0$ for negative statements. The summated scores of the $\mathrm{MCl}$ yielded a range of scores 
with minimum value of 8 , maximum value of 46 and mean value of 32 . The mean value served as a cut-off point between favourable disposition $(\geq 32)$ and unfavourable disposition $(<32)$. In order to assess the level of contraceptive use by married couples, ten methods of contraception - identified through literature and interviews - were presented to the respondents in a 3-point rating scale called the Contraceptive Use Scale (CUS). The three points in the CUS were assigned nominal values as follows: Never Use $=0$, Rarely Use $=1$ and Often Use $=2$. A mean cut-off point of 1.00, computed by summing up the ratings 0,1 and 2 and dividing by the number of ratings, was used to determine the level of use of each contraceptive method. The influence of spousal communication about family planning on the use of contraceptives by the respondents was analyzed using multiple regressions adapted from Ukpong (2016) who used a similar regression model to ascertain the determinants of contraceptive use by rural women in Ibiono Ibom Local Government Area of Akwa Ibom State. The multiple regression model is stated implicitly as:

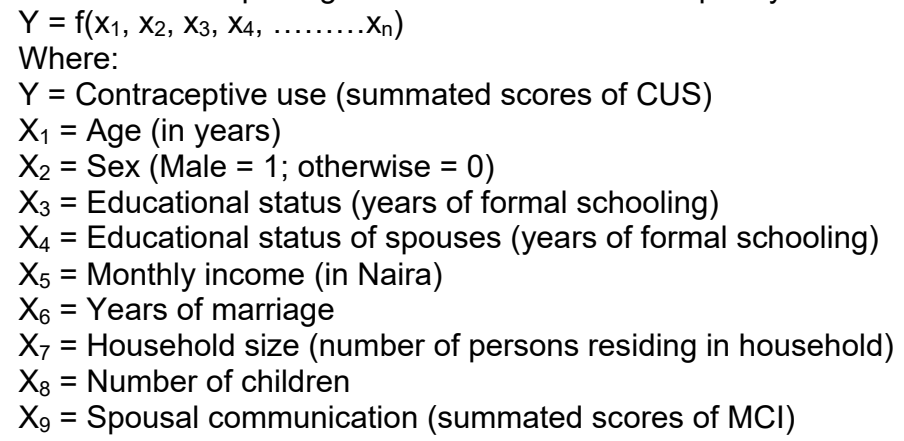

\section{Results and Discussion}

\subsection{Demographic Characteristics of Married Couples in Rural Areas of Akwa Ibom State, Nigeria}

The age and sex distribution of the respondents is presented in Table 1 separately from other demographic characteristics. This is done because the study was focused only on married couples of reproductive age. Married women above 51 years were not included in the study because they were considered to have reached menopause age hence do not need to use contraceptives. The Table shows that $71.3 \%$ of the respondents were females with an average age of 38 years while $28.7 \%$ of them were males with an average age of 49 years. The ages of married men in the rural areas of Akwa Ibom State are always relatively higher than that of the married women since females marry at earlier ages than males in the State (Asa and Solomon, 2010).

Table 1: Age and Sex Distribution of Married Couples in the Rural Areas of Akwa Ibom State

\begin{tabular}{lllll}
\hline Age class & \multicolumn{2}{l}{ Female respondents } & \multicolumn{2}{l}{ Male respondents } \\
& Frequency & Percentage & Frequency & Percentage \\
\hline $21-30$ years & 14 & 13.1 & 5 & 11.6 \\
$31-40$ years & 47 & 43.9 & 7 & 16.3 \\
$41-50$ years & 46 & 43.0 & 10 & 23.3 \\
$51-60$ years & - & - & 12 & 27.9 \\
$61-70$ years & - & - & 9 & 20.9 \\
Total & 107 & 100 & 43 & 100 \\
\hline
\end{tabular}

Source: Field Survey, 2016

Other demographic characteristics of the respondents such as educational status, educational status of the spouses of the respondents, monthly income, household size, years of marriage and 
number of children are shown in Table 2. Majority of the respondents (80\%) as well as majority of spouses of the respondents $(80 \%)$ had post-primary education revealing a high level of literacy among married couples in the study area. The findings agree with Asa (2015) who reported that the level of literacy among rural dwellers in Akwa lbom State is high. Table 2 also shows that the average monthly income of the respondents is N54,000.50 which is relatively low. Asa and Solomon (2010) also reported a low level of income among rural dwellers in Akwa lbom State. The average household size of the married couples comprised of seven persons and their average years of marriage is fourteen years. The high value placed on marriage in the rural areas of Akwa Ibom State which predispose rural women in the study area to marry at relatively early ages could be a contributory factor to the high average years of marriage of the respondents. About $67.3 \%$ of the respondents had $1-5$ children while $2.7 \%$ of them were childless.

Table 2: Demographic Characteristics of Married Couples in Rural Areas of Akwa Ibom State

\begin{tabular}{|c|c|c|c|}
\hline Characteristics & Categories & Frequency & Percentage \\
\hline \multirow[t]{3}{*}{ Educational status } & No formal education & 3 & 2.0 \\
\hline & Primary education & 27 & 18.0 \\
\hline & Post-primary education & 120 & 80.0 \\
\hline \multirow{3}{*}{$\begin{array}{l}\text { Educational status } \\
\text { of spouses }\end{array}$} & No formal education & 6 & 4.0 \\
\hline & Primary education & 24 & 16.0 \\
\hline & Post-primary education & 120 & 80.0 \\
\hline \multirow[t]{3}{*}{ Monthly income } & $1-100,000$ & 145 & 96.7 \\
\hline & $100,001-200,000$ & 4 & 2.7 \\
\hline & $200,001-300,000$ & 1 & 0.7 \\
\hline \multirow[t]{4}{*}{ Household size } & $1-5$ person(s) & 50 & 33.3 \\
\hline & $6-10$ persons & 93 & 62.0 \\
\hline & $11-15$ persons & 6 & 4.0 \\
\hline & $16-20$ persons & 1 & 0.7 \\
\hline \multirow[t]{4}{*}{ Years of marriage } & $1-10$ year(s) & 65 & 43.3 \\
\hline & $11-20$ years & 54 & 36.0 \\
\hline & $21-30$ years & 27 & 18.0 \\
\hline & $31-40$ years & 4 & 2.7 \\
\hline \multirow[t]{3}{*}{ Number of children } & None & 4 & 2.7 \\
\hline & $1-5$ & 101 & 67.3 \\
\hline & $6-10$ & 45 & 30.0 \\
\hline
\end{tabular}
January 24, 2017.

Source: Field Survey Data, 2016

\subsection{Spousal Communication about Family Planning Disposition of Married Couples in Rural Areas of Akwa Ibom State}

The respondents' disposition toward spousal communication about family planning, ascertained using the mean of the summated scores of the Marital Communication Inventory, is presented in Table 3. The Table reveals that $70.7 \%$ of the respondents had a favourable disposition while $29.3 \%$ of them had an unfavourable disposition. The finding agrees with Asa (2016) who reported a high level of favourable spousal communication disposition among married couples in rural areas of Akwa Ibom State. 
Table 3: Distribution of respondents based on spousal communication about family planning disposition

\begin{tabular}{lccc}
\hline Disposition & $\begin{array}{l}\text { Summated score of Marital } \\
\text { Communication Inventory }\end{array}$ & Frequency & Percentage \\
\hline Unfavourable & $<32$ & 44 & 29.3 \\
Favourable & $\geq 32$ & 106 & 70.7 \\
Total & & 150 & 100 \\
\hline
\end{tabular}

Source: Field survey data, 2016

\subsection{Level of Use of Contraceptives by Married Couples in Rural Areas of Akwa Ibom State}

Table 4 shows the level of use of contraceptives by the respondents. The contraceptive methods that are highly used by the respondents, as shown in Table 4 , are barrier methods $(\bar{x}=1.81)$, hormonal contraceptives $(\bar{x}=1.67)$, injectables $(\bar{x}=1.29)$ and abstinence $(\bar{x}=1.06)$. The finding is synonymous with Olugbenga-Bello et al., (2011) who reported that barrier methods and hormonal contraceptives are the most utilized contraceptive methods in rural communities of Nigeria. On the other hand, sterilization $(\bar{x}=0.16)$; contraceptive implants $(\bar{x}=0.58)$; voluntary surgical contraception $(\bar{x}=0.62)$; intra-uterine devices $(\bar{x}=0.71)$; and traditional methods of contraception such as use of beads, drinking salt-lime solution, extensive breast-feeding of babies and drinking herbs/roots mixture $(\bar{x}=0.93)$ were lowly used contraceptive methods in the study area. Sterilization is most lowly used because rural dwellers in Akwa lbom State perceive sterilization as a contraceptive method that predispose users of the method to unhealthy side effects (Asa and Daniel, 2015; Ukpong, 2016).

Table 4: Distribution of respondents based on level of use of contraceptive methods

\begin{tabular}{lll}
\hline Contraceptive methods & Mean & Rank \\
\hline 1. Contraceptive implants & 0.58 & Low \\
2. Voluntary surgical conception & 0.62 & Low \\
3. Injectables & 1.29 & High \\
4. Abstinence & 1.06 & High \\
5. Intra-uterine devices & 0.71 & Low \\
6. Barier methods (condoms, diaphragms) & 1.81 & High \\
7. Coitus intemuptus & 0.02 & Low \\
8. Hormonal contraceptives (pills) & 1.67 & High \\
9. Sterilization & 0.16 & Low \\
10. Traditional methods (beads, salt-lime drink, & 0.93 & Low \\
extensive breast-feeding of babies, herbs/roots & & \\
mixture) & & \\
\hline
\end{tabular}

Source: Field survey, 2016

3.4 Relationship between Spousal Communication about Family Planning and Contraceptive Use by Married Couples in the Rural Areas of Akwa Ibom State

The multiple regression analysis result showing the influence of the respondents' spousal communication about family planning on their contraceptive use is shown in Table 5 . Result in Table 5 reveal that spousal communication about family planning - with other factors such as age, 
educational status of the respondents, educational status of spouses of the respondents, income, number of children - significantly influence the use of contraceptives by married couples in the study area. Spousal communication about family planning is statistically significant at $10 \%$ level and carries a positive sign implying that the more favourable the respondents' disposition is, the higher the likelihood and intensity of contraceptive use among the couples. The finding is synonymous with previous works on contraceptive use which reported that couples who discuss contraceptive use and family planning are more likely to use contraceptives than those who do not (Shrestha, 2000; Sharan and Valente, 2002; Tuloro et al., 2006; Ogunjuyigbe et al., 2009; Link, 2011; Undelikwo et al., 2013). Discussions on contraceptives allow couples in a marriage to exchange views/ideas, and these discussions change some wrong/erroneous beliefs about contraceptive use thereby enhancing its use among the couples (Akafua and Sosson, 2008).

Table 5: Multiple regression analysis result showing the relationship between spousal communication and contraceptive use among married couples in the study area

\begin{tabular}{llll}
\hline Variables & Coefficient & Standard error & $\mathrm{t}$ \\
\hline Age & 0.610 & 0.302 & $2.020^{* *}$ \\
Sex & 0.030 & 0.038 & 0.789 \\
Educational status & 0.073 & 0.040 & $1.825^{*}$ \\
Educational status of spouses & 0.223 & 0.103 & $2.163^{* *}$ \\
Income & 0.312 & 0.118 & $2.645^{* *}$ \\
Years of marriage & -0.003 & 0.002 & -1.500 \\
Household size & 0.001 & 0.007 & 0.143 \\
Number of children & 0.407 & 0.176 & $2.313^{* *}$ \\
Spousal communication & 0.479 & 0.212 & $2.260^{* *}$ \\
Constant & 0.309 & 0.122 & $2.535^{* *}$ \\
$\mathrm{R}^{2}$ & 0.729 & & \\
\hline Note: * and ** significance at 10\% and 5\% levels respectively &
\end{tabular}

Source: Computed from SPSS Version 20.0

\section{Conclusion and Recommendations}

The study ascertained the influence of married couples' spousal communication about family/planning on their use of contraceptives in the rural areas of Akwa Ibom State, Nigeria. The results indicate that barrier methods, hormonal contraceptives, injectables and abstinence were contraceptive methods highly used by the respondents, and that majority of the respondents had a favourable spousal communication about family planning disposition. Contraceptive use by married couples in the rural areas of Akwa Ibom State, Nigeria is significantly influenced by spousal communication about family planning. Based on the findings of the study, the following recommendations are made:

i. Intervention programmes of Governmental and Non-Governmental agencies in Akwa Ibom State, Nigeria aimed at reduction of the increasing population in the State should emphasis the importance of spousal communication about family planning/contraceptive use in their programmes, and encourage same among the targeted beneficiaries of such programmes since spousal communication about family planning among married couples 
significantly influenced contraceptive use by the couples.

ii. The Government, Non-Governmental Organizations (NGOs) and development agencies in Akwa lbom State, Nigeria should embark on enlightenment campaigns aimed at combating/changing the negative perceptions of certain contraceptive methods such as sterilization and coitus interruptus which are lowly used in the rural areas of the State due to negative perceptions about them as reported in this study.

\section{References}

Adeoti, A. I., Oni, O. A., Alonge, S. K. and Akintunde, O. O. (2009) Demand for reproductive health, poverty and economic growth in Nigeria. Paper presented at the Conference Centre for the Study of African Economics, Department of Economics, Oxford University.

Adewole, A. O. (2012) Effect of population on economic development in Nigeria: A quantitative assessment, International Journal of Physical and Social Sciences, 2(5): $1-4$.

Akanbi, M. A., Ogbari, M. E., Akinbola, O. A., Amusan, T. A. and Ogunmiloro, S. F. (2011) The effect of interpersonal communication on contraceptive use among married couples in Alimosho Local Government Area of Ipaja, Lagos State, Nigeria, An Interdisciplinary Journal of the Nigerian Sociological Society and Development, 1(3).

Akafua, R. A. and Sossou, M. (2008) Attitude towards and use of knowledge about family planning among Ghanaian men. Accessed from http://www.thefreelibrary.com on October 3, 2011.

Asa, U. A. (2006) Perceived effect of Akwa Rubber Estates Limited (AKRUBEL) on rural livelihoods in Akwa Ibom State, Nigerian Journal of Agriculture, Food and Environment, 3 (1 \& 2): 52 - 55.

. (2015) Constraints to mobile phones utilization by rural dwellers in Akwa Ibom State, Nigeria, International Journal of Information and Communication Technology Research, 5(2): 28 - 34.

(2016) Barriers to spousal communication among married couples in rural areas of Akwa lbom State, Akwapoly Journal of Communication and Scientific Research, 1(1): $14-23$.

Asa, U. A. and Daniel, E. A. (2015) Barriers to contraceptive use among rural farmers in Akwa lbom State, Nigeria, International Journal of Agricultural Extension and Rural Development Studies, 2(1): 22 - 29.

Asa, U. A. and Solomon, V. A. (2010) Gender participation in livelihood activities of rural dwellers in Akwa Ibom State, Nigeria, International Journal of Applied Agricultural and Apicultural Research, 6(1 \& 2): $57-64$.

Asthana, D. K. and Asthana, M. (2006). A Textbook of Environmental Studies. New Delhi: S. Chand and Company.

Eastwood, R. and Lipton, M. (2001) Demographic Transition and Poverty: Effects via Economic Growth and Poverty in the Developing World. Oxford: Oxford University Press.

Islam, M.S., Alam, M. S. and Hasan, M. M. (2014) Inter-spousal communication on family planning and its effect on contraceptive use and method choice in Bangladesh, Asian Social Science, 102(2): $189-201$.

Kamal, N. (1999). Inter-spousal communication on family planning as a determinant of the use of modern contraception in Bangladesh, Journal of Family Welfare, 45(1): $34-43$.

Link, C. F. (2011) Spousal communication and contraceptive use in Rural Nepal: An event history analysis, Studies in Family Planning, 42(2): 83 - 102.

Longwe, A., Huisman, J. and Smiths, J. (2012) Effects of knowledge, acceptance and use of contraceptives on household wealth in 26 African Countries, NiCE Working Paper 12 - 109, Institute for Management Research, Radbond University, Nijmegen, The Netherlands. 22pp.

May, J. F. (2012) World Population Policies: Their Origin, Evolution and Impact. New York: Springer - Verlag.

National Population Commission (2006) Population and Housing Census of the Federal Republic of Nigeria. Analytical Report at the National Population Commission, Abuja, Nigeria.

National Population Commission/Federal Ministry of Health (NPC/FMOH) 2004. Population and the Quality of Life in Nigeria. Abuja: National Population Commission.

Ogunjuyigbe, P. O., Ojofetimi, E. O. and Liasu, A. (2009) Spousal communication, changes in partner attitude and contraceptive use among Yorubas of South West Nigeria. Incl. J. Comm. Med., 34(2): 22.

Okoroafor, O. E. (2001). Large Families: Causes, Consequences and Cures. Owerri: Spring Field Publishers Ltd.

Olugbenga-Bello, A. I., Abodunrin, O. L. and Adeomi, A. A. (2011), Contraceptive practices among women in rural communities in South-Western Nigeria, Global Journal of Medical Research, 11(1): 14 - 16.

Sharan, M. and Valente, T. W. (2002) Spousal communication and family planning adoption: Effects of a radio drama serial in Nepal, International Family Planning Perspectives, 28(1).

Shrestha, D. P. (2000) Determinants of current contraceptive use among Nepal's women: An analysis of NFH Survey 1991, Nepal Population and Development Journal, 1 - 9. 
Tuloro, T., Deressa, W., Ali, A. and Davey, G. (2006). The role of men in contraceptive use and fertility preference in Hossana Town, Southern Ethiopia, Ethiopia Journal of Health Development, 20(3): 1 - 8.

Ukpong, A. I. (2012). Determinants of contraceptive use by rural women in Ibiono Ibom Local Government Area, Akwa Ibom State, B. Agric, Department of Agricultural Economics and Extension, University of Uyo, Uyo. 88pp.

Undelikwo, V. A., Osonwa, O. K., Ushie, M. A. and Osonwa, R. H. (2013) Family planning behaviours and decision-making among couples in Cross River State, Nigeria, International Journal of Learning and Development, 3(1). 